\title{
CONSTRUCTION AND DEMOLITION WASTE MANAGEMENT LEGISLATION AND FRAMEWORK IN INDIA - A MINI REVIEW WITH BEST PRACTICES IN C \& D WASTE MANAGEMENT
}

\author{
Yogesh Kumar Raj*1, Ar. S Choudhary ${ }^{2}$ \\ ${ }^{1}$ Post Graduate Student, Faculty of Design, Vivekanand Global University, Jaipur \\ ${ }^{2}$ Assosciate Professor, Faculty of Design, Vivekanand Global University, Jaipur
}

Article DOI: https://doi.org/10.36713/epra7388

DOI No: 10.36713/epra7388

\begin{abstract}
The construction industry in Indian cities has grown rapidly in recent decades due to population growth, industrialization and the introduction of new infrastructure projects, which has led to a tremendous growth in the construction industry. A key demand as a result of the growth of the Indian construction sector is expected to be the supply gap in terms of construction materials such as sand, limestone, and aggregate. The Supreme Court has had a major impact on the construction industry due to the ban on river sand and stone mining. It is designed to find an alternative source of natural raw materials. An alternative source in the field of aggregate construction recycled by $C \& D$ Waste could replace a significant amount of natural aggregates that run abroad in countries such as the United States, France, Denmark, Germany and Japan. Has been While various methods of waste have been suggested in the literature, the quantification of waste produced in India is insufficient. This inadequacy is due to lack of proper classification control procedures, lack of joint C\&D waste estimation procedures, and knowledge of $C \& D$ waste processing among generators, collectors, operators, regulators, and the general public. The C\&DWaste Management Rules 2016 to address the responsibilities of all stakeholders for the systematic collection, storage, transport, treatment / processing, and disposal of C\&D bins in India was introduced. This comprehensive study seeks to analyze current legislation and challenges, and proposes an informational framework for systematic collection, storage, treatment / processing, and C\&D waste disposal.This article examines the current methods of C\&D waste in India. It also studies the institutional, regulatory and legislative framework in India in the field of construction and demolition waste management.
\end{abstract}

KEY WORDS- Construction and demolition waste management, legislation, framework, best practices

\section{INTRODUCTION}

Construction and Demolition Work (C\&D) Waste refers to the demolition of any type of building material, debris, and debris and civil structures such as houses, bridges, roads, dams, large building structures, and others. , Repair, Modeling and Demolition of Component Infrastructure (MOEFCC, 2016). The construction industry in India is booming. Already at $10 \%$ of GDP, it has been growing at an annual rate of $10 \%$ over the last 10 years while its global average is $5.5 \%$ per annum. About $70 \%$ of the building stock in India is still outstanding. The area is expected to expand from 21 billion square feet in 2005 to 530 billion and 104 billion square feet by 2030. This will be the result of a huge increase. Buildings and infrastructure are our basic needs for water, energy and materials.But they also produce waste. The Union Ministry of Forests and Environment (MOEF) has acknowledged that there is no systematic database on C\&D waste. According to estimates by the Center for Science and Environment (CSE), since 2005, India has built an additional 5.75 


\section{EPRA International Journal of Research and Development (IJRD)}

Volume: 6 | Issue: 6 | June 2021

- Peer Reviewed Journal

billion square meters in 2013 alone, with approximately one billion square meters.If a new construction (according to the Council of Technology Information, Forecasting and Evaluation, or TIFAC, according to the Thumb Principle) produces $40-60 \mathrm{~kg}$ of C\&D waste per square meter, the average is $50 \mathrm{~kg}$. Per square meter, India should generate 50 million tonnes (MT) of C\&D waste in 2013. Over the past eight years, it has produced $287 \mathrm{MT}$ of this waste.

According to one estimate construction waste alone is 14.5 million tonnes. Construction and demolition waste in India is estimated at 24 million tonnes during 2010 (Shetty, 2013).If measures to minimize and handle construction and demolition waste are not adopted in a developed and efficient manner, it can have an impact on the environment. This estimate is for new construction only.

Waste related to demolition and renovation / repair of old stock produces additional waste. For every square meter of demolition, there is 10 times the amount of waste generated during construction, according to TIFAC, 300 to 500 kilograms of waste per square meter.Assuming that five percent of the existing building's stockpile has been destroyed and that it has been completely rebuilt annually, the demolition alone would have generated only 288 MT more Clu0026D waste in 2014. So, in just one year in India - in 2014, the CD D waste generated by buildings is equivalent to an ideal 30 megatons, which is 44 times more than the official estimate.

Imagine a scenario if waste generated from infrastructure projects such as roads and dams is included. Not surprisingly, in India, if the amount of C\&D dustbin is corrected, it will be dumped along with all other types of solid waste. As per the report prepared by MOEF (Ministry of Environment and Forests) in 2008 , the country produces 0.53 million tons / day of waste. On this basis, 210 million tons of MSW is produced annually, Below Table shows the estimate prepared by the Central Government of India. But as the World Bank report states, Asian countries produce about 1,000 to 1,000 kilograms per capita each year, which means that the figures reported by the MOEF are much lower than the World Bank report. Are The show has seemed a bit unfocused in recent episodes in India. Below Figure, which has a graphical representation, shows the daily production of construction and demolition waste in Indian cities.

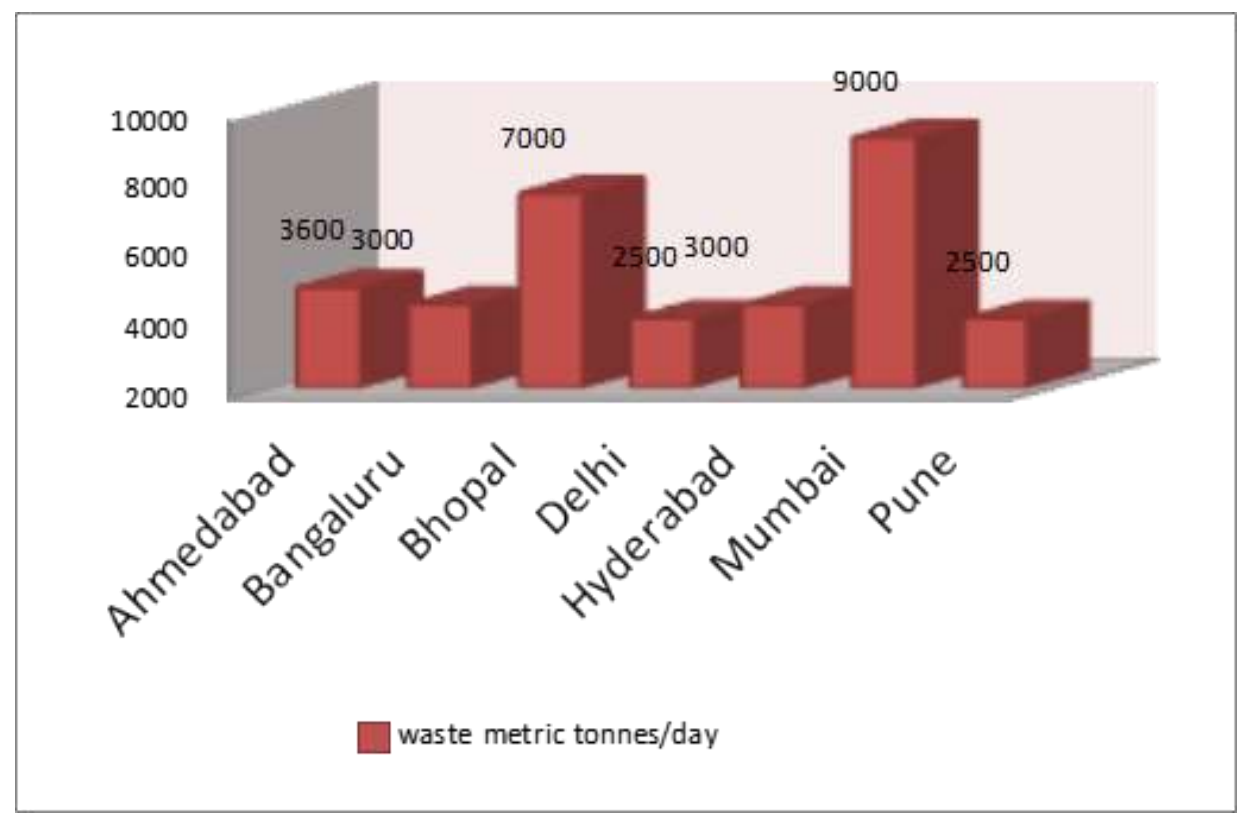

Waste generation in Indian cities
\begin{tabular}{|c|c|c|}
\hline Year & Authority & $\begin{array}{c}\text { Sstimate in Million } \\
\text { Tonnes }\end{array}$ \\
\hline 2000 & Ministry of Urban Development(2000) & $10-12$ \\
\hline 2001 & TIFAC (2000) & $12-15$ \\
\hline 2010 & Ministry of Environment and Forest & $10-12$ \\
\hline 2014 & Ministry of Urban Development(2014) & no estimate exist \\
\hline
\end{tabular}

Estimate Prepared by Central Govt. Source: MOEF report 


\section{COMPOSITION OF CONSTRUCTION WASTE GENERATED IN INDIA}

The construction waste of the mixture depends on the type of structure. For example, if the structure is a flyover or a bridge structure, its structure will usually be solid and steel. On the other hand, if residential structures are built or demolished, the structure will be real, including concrete, steel, wood, tile, paint, plastic, etc.

\begin{tabular}{|c|c|c|c|}
\hline $\begin{array}{c}\text { Components } \\
\text { of C \& D waste }\end{array}$ & TIFAC (\%) & $\begin{array}{c}\text { MCD } \\
\text { Survey (\%) }\end{array}$ & $\begin{array}{c}\text { Survey } \\
\text { IL \& FS (\%) }\end{array}$ \\
\hline soil/sand, Gravel & 36.0 & 43.0 & 31.5 \\
\hline Bitumen & 2.0 & - & - \\
\hline Metals & 5.0 & - & 0.4 \\
\hline Concrete & 23.0 & 35.0 & - \\
\hline Wood & 2.0 & 2.0 & 1.5 \\
\hline Others & 1.0 & 1.0 & 7.6 \\
\hline
\end{tabular}

Source:Gayakwad,HarishP.(2000)

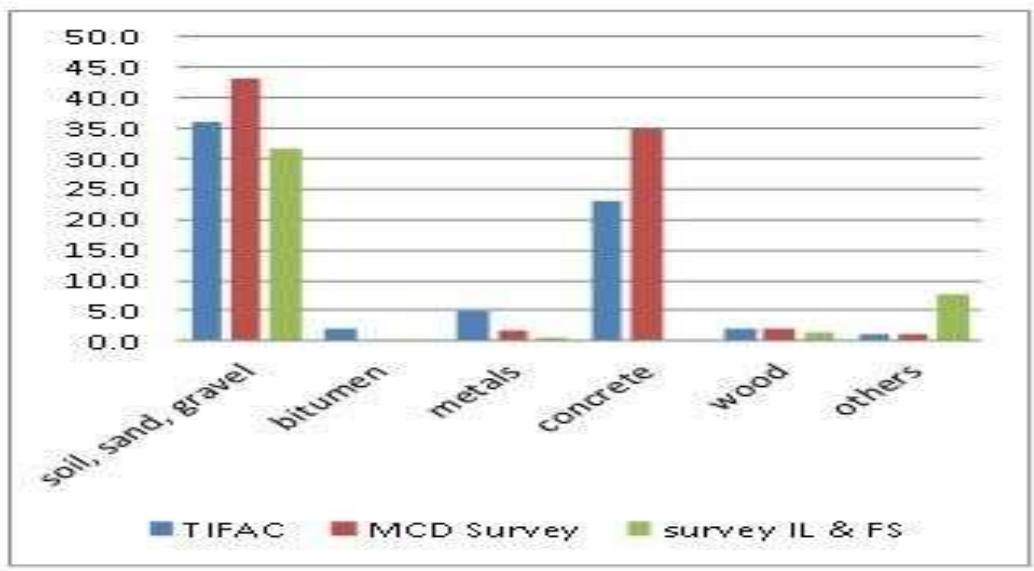

Typical Composition of Indian Construction Wast

Source:Gayakwad,HarishP.(2000) that the infrastructure and real estate sectors are the

\section{SOURCES OF WASTE GENERATION} IN THE CONSTRUCTION INDUSTRY

In the last decade, the construction sector in India has shown its rapid growth, leading to development and rehabilitation projects in India. There are usually two sources of waste, bulk generators and retail generators or small generators. From the classification of sources, data is provided total generators of waste production.Construction and repair of roads, bridges, flyovers etc. are classified under the Department of Infrastructure Development. The real estate sector has construction of houses, industrial and commercial buildings, demolition of unauthorised structures etc. Small businesses and individual housing buildings are considered retail or small generators (Job Thomas, Wilson PM). 


\section{EPRA International Journal of Research and Development (IJRD)}

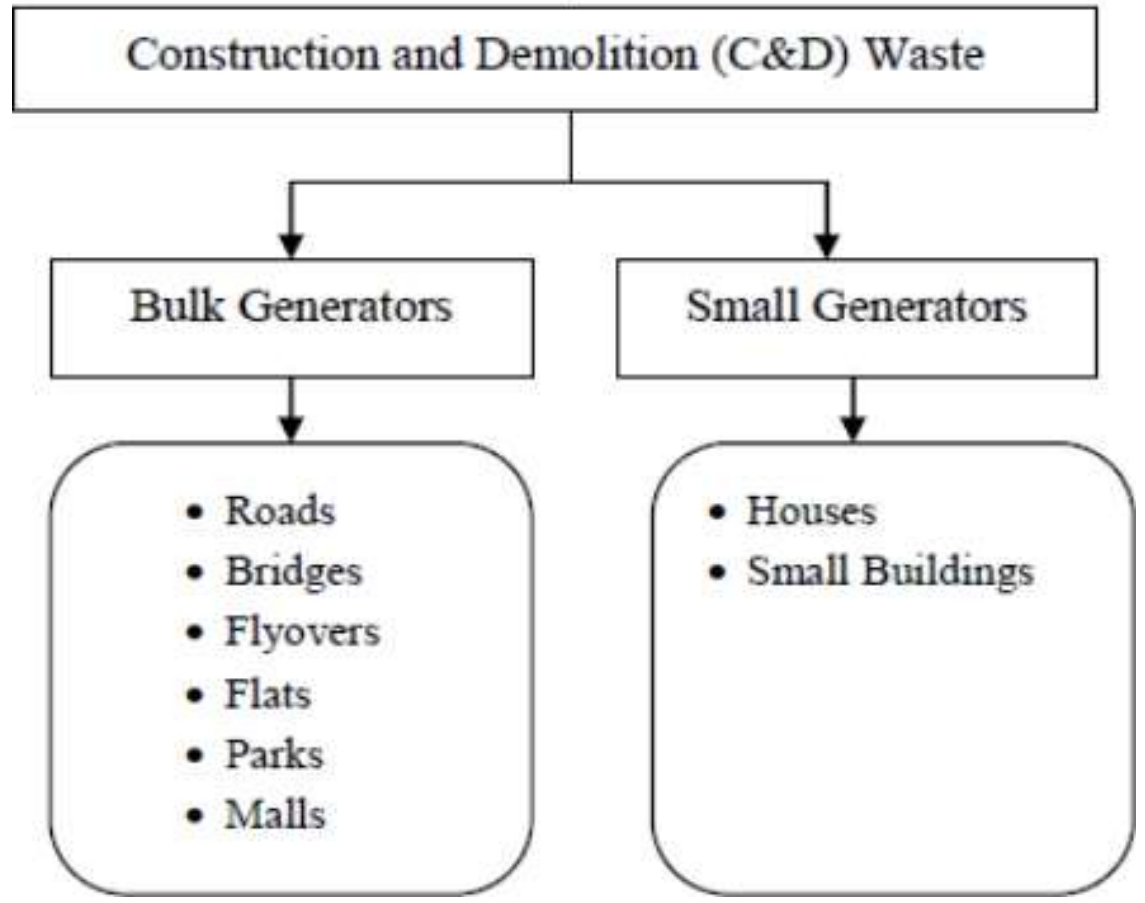

Figure-4: Sources of Generation of Construction and Demolition Waste

\section{MATERIAL CONSUMTION IN INDIAN CONSTRUCTION INDUSTRY}

In 2007, the construction sector was the second largest sector in India in terms of material consumption. With the increase in absolute material consumption by more than a billion tonnes, the construction sector was the fastest growing sector between 1997 and 2007 (TERI et al., 2016). At such a rate of growth, the construction sector is expected to surpass the agriculture sector by 2020 and become the most material-consuming sector in India. The main ingredients used are sand/fine accumulation (concrete and mortar), stone/gravel (for rough bulk), soil (for brick production), iron and steel (for bars and stems), and lime (for cement production) as Indian Consultant (TERI et al., 2016).

The increase in construction activity has put more demands on building materials, with demand for sand particularly high (CSTEP, 2016). The annual consumption of construction materials in India was 750 million tonnes (MT) of sand, 242 metric lime, 2 billion tonnes of stone (aggregate) and 350 million m3 of soil in 2018 (MoHUA and NITI Aayog, 2018). The total annual demand in Karnataka alone is estimated at 26 MT in 2014 and is expected to grow up to 56-81 MT per annum till 2030 (CSTEP, 2016; Sundar and Asundi, 2015). India is the second largest producer of cement globally, which accounts for about $6.3 \%$ of global cement production (Department of Industrial Policy and Development, 2011; Teri et al., 2016). At the current growth rate, cement production in India is expected to increase 4-7 times by 2050 and By 2030 India may be draining its substantial limestone reserves (IEA and WBCSD, 2018; IGEP, 2013).In order to meet the demand of limestone for steel and chemical industries in India and the resulting shortage of limestone for cement production, the net cement imports in India increased from $1 \mathrm{MT}$ in 2000 to $4 \mathrm{MT}$ in 2010 (IGEP, 2013). Furthermore, the cement industry is one of the largest emitters of $\mathrm{CO} 2$, and accounts for approximately $7 \%$ of total $\mathrm{CO} 2$ emissions in India (IEA and WBCSD, 2018).

\section{C \& D WASTE GENERATION IN INDIA AND ITS QUANTIFICATION METHODS}

The construction sector was the second largest sector in India in terms of material consumption in 2007. With an increase in absolute material consumption by more than one billion tonnes, the construction sector was the fastest growing sector between 1997 and 2007 (TERI et al., 2016).

Several methods have been developed to quantify C\&D waste at regional and project levels. One such method developed by the Technology Information Forecasting and Assessment Council (TIFAC) is based on the waste generated during different activities (CPCB, 2017):

(a) $40-60 \mathrm{~kg} \mathrm{~m}-2$ of new construction;

(b) $40-50 \mathrm{~kg} \mathrm{~m}-2$ of building repair; 


\section{EPRA International Journal of Research and Development (IJRD)}

(c) 300-500 kg m-2 of building demolition.

Empirical estimations may be used for C\&D waste quantification under certain specific conditions. However, some other useful methodologies have been developed to quantify $\mathrm{C} \& \mathrm{D}$ waste using direct/indirect measurements, waste generation factors/ multipliers, building/material lifetime estimates, economic indicators, etc. The precise quantities of $C \& D$ waste generation in India are uncertain (CPCB, 2017). This can be attributed to various factors.

1. Site Visit (SV) method: This method involves the direct or indirect measurement of C\&D waste bundertaking visits to construction or demolition sites. Direct measurement requires weighing the waste or measuring its volume on-site. Indirect method employs truck load records to estimate the volume of waste generated on a construction/demolition site or a landfill (Kartam et al., 2004; Poon et al., 2004b; Wu et al., 2014).

2.Generation Rate Calculation (GRC) method: GRC method is a common technique of waste generation estimation by using the waste generation rate for a particular activity unit. Several alternative parameters such as per capita multiplier, financial value extrapolation, and area-based calculations can be employed to obtain waste generation ( $\mathrm{Wu}$ et al., 2014). The waste generation rate principle has been used to estimate building-related $\mathrm{C} \& \mathrm{D}$ waste generation in cities like Chennai (Ram and Kalidindi, 2017).

3. Lifetime Analysis (LA) method: Constructed buildings are ultimately demolished and become demolition waste. Hence, the amount of demolition waste must equal the mass of constructed structure and can be estimated by assuming reasonable lifetime of buildings and materials, and accounting for the material consumption and typical waste factors for construction materials (Poon, 1997; Wu et al., 2014).4. Classification System Accumulation (CSA) method: This method of calculating waste generation is based on the GRC method. The primary improvement over the GRC method is that this methodology uses a classification system which provides a platform for quantifying different specified material (Wu et al., 2014).

5. Variables Modelling (VM) method: C\&D waste generation depends on variables such as economic indicators, construction areas, working conditions, etc., which help in the simulation of C\&D waste generation using variables modelling ( $\mathrm{Wu}$ et al., 2014). Some studies have adopted this approach to understand the time-dependent accumulation rate of C\&D waste (Kern et al., 2015, S'aez et al., 2014).

\section{C\&D WASTE MANAGEMENT LEGISLATION IN INDIA}

C\&D waste in India was traditionally considered as a component of MSW and has therefore been addressed on a very limited scale in the legislations governing MSW management. However, increasing quantities of C\&D waste mixed with MSW creates major problems at the MSW processing facilities. The proper management, reuse, and processing of C\&D waste has been the focus of various governmental agencies since 2010 (BMTPC,

2018). A chronological review of key waste management legislations, guidelines, and standards concerning C\&D waste is useful in tracing the evolution of $\mathrm{C} \& \mathrm{D}$ waste management practices as well as the continual challenges posed by C\&D waste in India (Table 1).

The C\&D Waste Management Rules 2016 were implemented in India with primary focus on management of C\&D waste based on the principles of reuse and recycling, and ensuring planned processing and disposal of C\&D waste.

1. The C\&D Waste Management Rules 2016 explicitly define the duties of the waste generator, service provider and its contractors, local authority, State Pollution Control Board (SPCB) / Pollution Control Committee (PCC), State Government/Union Territory Administration, Central Pollution Control Board (CPCB) and the Central Government in an organized waste management mechanism.

2. Schedule I of the Rule specifies detailed criteria for site selection for storage and processing or Recycling facilities for $C \& D$ waste.

3. Schedule III of the Rule stipulates a specified timeframe for planning and implementation of the provisions provided therein by various enforcing bodies/authorities.

4. The Rule provides for reporting of any accident in a C\&D waste processing or treatment or disposal facility to the local authority.

Manuja et al. (2016) identified some limitations and recommended measures to improve upon the operative part of the C\&D Waste Management Rules 2016.

1. A list of expert institutions and civil society groups which can be utilized for consultation or creation of a sustained system of Information, Education, and Communication (IEC) for C\&D waste may be included in the legislation for public interest.

2. The possibility of utilizing C\&D waste as a cover material for sanitary landfill has not 


\section{EPRA International Journal of Research and Development (IJRD)}

Volume: 6 | Issue: 6 | June 2021

- Peer Reviewed Journal

been proposed in the C\&D Rules of 2016. An action plan for utilizing C\&D waste as landfill cover can be a viable disposal method of unprocessed $\mathrm{C} \& \mathrm{D}$ waste.

3. To avoid arbitrary user charges, the location and composition of C\&D waste may be used as the basis for calculation of fixed charges payable by the waste generator for collection, transportation, processing and disposal of C\&D waste.
Some other measures which can be adopted to ensure effective management of C\&D waste include setting up of specific targets to achieve recycling of C\&D waste, tax exemption on usage of recycled concrete aggregate to encourage use of recycled $\mathrm{C} \& \mathrm{D}$ waste, and investing efforts in IEC campaigns to spread awareness on reuse and recycling of C\&D waste (Ramanathan, 2018).

\section{CONSTRUCTION AND DEMOLITION (C\&D) WASTE MANAGEMENT LEGISLATIONS IN INDIA}

\begin{tabular}{|c|c|c|c|}
\hline Year & Legislation/Guidelines & Contents & $\begin{array}{c}\text { Issuing Authority } \\
\text { Department }\end{array}$ \\
\hline 2000 & $\begin{array}{l}\text { Schedule III of Municipal Solid } \\
\text { Waste (Management and } \\
\text { Handling) Rules, } 2000\end{array}$ & A description of C\&D waste & $\begin{array}{l}\text { Ministry of Environment } \\
\text { and } \\
\text { Forests, Govt. of India }\end{array}$ \\
\hline 2000 & $\begin{array}{l}\text { Manual on Municipal Solid } \\
\text { Waste Management }\end{array}$ & $\begin{array}{l}\text { A chapter on C\&D waste laying down } \\
\text { basic guidelines on C\&D waste } \\
\text { handling }\end{array}$ & $\begin{array}{l}\text { Ministry of } \\
\text { Development } \\
\text { Govt. of India }\end{array}$ \\
\hline 2006 & $\begin{array}{l}\text { Construction \& Demolition and } \\
\text { Desilting Waste (Management } \\
\text { and Disposal) Rules, } 2006\end{array}$ & C\&D waste management & $\begin{array}{l}\text { Municipal Corporation of } \\
\text { Greater Mumbai }\end{array}$ \\
\hline 2010 & $\begin{array}{l}\text { Report of the Working } \\
\text { Committee on Municipal Solid } \\
\text { Waste Management }\end{array}$ & $\begin{array}{l}\text { Recommendation of special focus on } \\
\text { C\&D waste }\end{array}$ & $\begin{array}{l}\text { Working Committee on } \\
\text { Municipal Solid Waste } \\
\text { Management }\end{array}$ \\
\hline 2012 & $\begin{array}{l}\text { Circular to set up C\&D waste } \\
\text { recycling facilities under } \\
\text { Swachh Bharat Mission (SBM) }\end{array}$ & $\begin{array}{l}\text { Setting up of C\&D waste recycling } \\
\text { facilities in all cities with population of } \\
\text { over } 1 \text { million (MoHUA and NITI Aayog, } \\
2018 \text { ) }\end{array}$ & MoUD, Govt. of India \\
\hline 2014 & $\begin{array}{l}\text { Guidelines for Sustainable } \\
\text { Habitat }\end{array}$ & $\begin{array}{l}\text { A chapter on 'Guidelines on re-use of } \\
\text { recycled C\&D waste' and ways and } \\
\text { precautions for recycling of C\&D waste } \\
\text { and emphasizing the need for a } \\
\text { deconstruction plan to recover } \\
\text { reusable products (BMTPC, 2018; } \\
\text { MoHUA and NITI Aayog, 2018) }\end{array}$ & $\begin{array}{l}\text { Central Public Works } \\
\text { Department } \\
\text { (CPWD), Ministry of } \\
\text { Housing and } \\
\text { Urban Affairs (MoHUA), } \\
\text { Govt. of } \\
\text { India }\end{array}$ \\
\hline 2015 & $\begin{array}{l}\text { Advisory on the use of recycled } \\
\text { products from C\&D waste }\end{array}$ & $\begin{array}{l}\text { Addition of a mandatory clause in all } \\
\text { future tenders for using } 2 \% \text { and } 10 \% \text { of } \\
\text { recycled C\&D waste products in } \\
\text { buildings and road works, respectively } \\
\text { (Government of NCT of Delhi, 2018) }\end{array}$ & $\begin{array}{l}\text { Public Works Department, } \\
\text { Govt. of } \\
\text { NCT of Delhi }\end{array}$ \\
\hline 2015 & $\begin{array}{l}\text { Draft Solid Waste Management } \\
\text { Rules, } 2015\end{array}$ & A chapter on C\&D waste management & $\begin{array}{l}\text { Ministry of Environment, } \\
\text { Forest and Climate Change } \\
\text { (MoEFCC), } \\
\text { Govt. of India }\end{array}$ \\
\hline 2016 & $\begin{array}{l}\text { Construction and Demolition } \\
\text { Waste Management Rules, } \\
2016\end{array}$ & $\begin{array}{l}\text { Rules governing waste resulting from } \\
\text { construction, re-modeling, repair and } \\
\text { demolition of any civil } \\
\text { structureindividual/organization/auth } \\
\text { ority who generate C\&D waste such as } \\
\text { building material, debris, or rubble } \\
\text { (MoEFCC, 2016) }\end{array}$ & MoEFCC, Govt. of India \\
\hline 2016 & $\begin{array}{l}\text { Guidelines for Utilization of } \\
\text { Construction and Demolition } \\
\text { Waste in Construction of } \\
\text { Dwelling Units and Related } \\
\text { Infrastructure in Housing } \\
\text { Schemes of the Government }\end{array}$ & $\begin{array}{l}\text { Address considerable shortage of } \\
\text { conventional building materials in } \\
\text { India based on high demand of building } \\
\text { materials by 2021-2022 (MoHUA and } \\
\text { NITI Aayog, 2018) }\end{array}$ & $\begin{array}{l}\text { Building Materials and } \\
\text { Technology Promotion } \\
\text { Council (BMTPC), } \\
\text { MoHUA, Govt. of India }\end{array}$ \\
\hline
\end{tabular}




\begin{tabular}{|c|c|c|c|}
\hline 2016 & $\begin{array}{l}\text { Notification on use of recycled } \\
\text { portions of C\&D waste }\end{array}$ & $\begin{array}{l}\text { Mandatory use of recycled portions of } \\
\text { C\&D waste in construction activities if } \\
\text { the same is available within } 100 \mathrm{~km} \text { of } \\
\text { the construction site (MoHUA and NITI } \\
\text { Aayog, 2018) }\end{array}$ & $\begin{array}{l}\text { CPWD, MoHUA, Govt. of } \\
\text { India }\end{array}$ \\
\hline 2016 & $\begin{array}{l}\text { Indian Standard (IS) 383: } 2016 \\
\text { 'Coarse and Fine Aggregate for } \\
\text { Concrete - Specification' (third } \\
\text { revision) }\end{array}$ & $\begin{array}{l}\text { Inclusion of fine and coarse aggregate } \\
\text { produced by recycling of C\&D waste } \\
\text { (BMTPC, 2018; IS 383: 2016) }\end{array}$ & $\begin{array}{l}\text { Bureau of Indian } \\
\text { Standards (BIS), Ministry } \\
\text { of Consumer Affairs,Food } \\
\text { and Public Distribution, } \\
\text { Govt. of India }\end{array}$ \\
\hline 2016 & $\begin{array}{l}\text { National Building Code of India } \\
2016 \text { (Volume 2) }\end{array}$ & $\begin{array}{l}\text { Recommendation to replace up to } 30 \% \\
\text { of natural crushed coarse aggregate by } \\
\text { coarse recycled concrete aggregate, in } \\
\text { fresh concrete. This percentage is to be } \\
\text { increased up to } 50 \% \text { for pavements } \\
\text { and other areas which are under pure } \\
\text { compression (BIS, 2016). }\end{array}$ & $\begin{array}{l}\text { Bureau of Indian } \\
\text { Standards (BIS), Ministry } \\
\text { of Consumer Affairs, Food } \\
\text { a Public Distribution, } \\
\text { Govt. of India }\end{array}$ \\
\hline 2017 & $\begin{array}{l}\text { Guidelines on Environmental } \\
\text { Management of Construction } \\
\text { and } \\
\text { Demolition Waste }\end{array}$ & $\begin{array}{l}\text { Integrated approach for environmental } \\
\text { management of C\&D Waste in } \\
\text { compliance with C\&D Waste } \\
\text { Management Rules, } 2016(\mathrm{CPCB}, 2017)\end{array}$ & $\begin{array}{l}\text { Central Pollution Control } \\
\text { Board (CPCB), MoEFCC, } \\
\text { Govt. of India }\end{array}$ \\
\hline 2017 & $\begin{array}{l}\text { Indian Roads Congress (IRC) } \\
\text { 121: } 2017\end{array}$ & $\begin{array}{l}\text { Guidelines for use of C\&D waste in } \\
\text { roads sector (MoHUA and NITI Aayog, } \\
2018 \text { ) }\end{array}$ & $\begin{array}{l}\text { Indian } \\
\text { (IRC) }\end{array}$ \\
\hline
\end{tabular}

\section{INDIAN C\&D WASTE MANAGEMENT FRAMEWORK}

The predicted demand growth of construction materials is expected to cause significant material supply problems in India (TERI et al., 2016). Supply bottlenecks have already affected prices and construction schedules in some parts of the country. The construction sector is particularly vulnerable to price instabilities since material costs typically account for more than $60 \%$ of the total cost of a building in India (TERI et al., 2016). The acute demand for recycled aggregates in the housing and road sectors to reduce the demand-supply gap, and the need to check resource depletion due to excessive sand mining are some other factors of immediate concern. On the other hand, large construction projects under government initiatives to fulfill housing demands and commercial infrastructure projects adds to the enormous quantities of $C \& D$ waste that remain unprocessed. The development of a framework for organized collection, storage, processing and disposal of $C \& D$ waste using the principles of reuse and recycling is an important step towards solving the dual problem of material shortage and waste accumulation (CPCB et al., 2017). An understanding of a typical C\&D waste processing system is essential to establish best practices within the information framework.

\section{BEST PRACTICES IN INDIAN C\&D WASTE MANAGEMENT}

Civic bodies, industries, and other organizations have become increasingly aware of the problems of C\&D waste and have begun to undertake some measures for C\&D waste processing. Several C\&D waste management projects that have been implemented across various locations in India can be reviewed and analyzed for best practices (BMTPC, 2018; Development Alternatives, 2017).

1. The first $C \& D$ waste processing plant in India was commissioned in 2010 at Burari in North Delhi under a Public Private Partnership (PPP) agreement between North Delhi Municipal Corporation and ILFS Environmental Infrastructure \& Services Ltd (IEISL) for treatment of 500 TPD C\&D waste on a pilot basis. The plant currently operates at a processing capacity of 2000 TPD and demonstrates an economically feasible business model that could be adopted across India. Both dry and wet processing have been adoptedto recycle and process about $95 \%$ of incoming C\&D waste into aggregates, manufactured sand, and finished products such as paver blocks, concrete bricks, drain slabs, etc. The produced materials meet Bureau of Indian Standards (BIS) codes for construction applications and have been recommended for preferential procurement by public agencies. Three other C\&D waste recycling plants have been commissioned by the Government of NCT of Delhi to cover all zones of Delhi. A second plant of capacity 500 TPD at Shastri Park in Delhi started operations in 2016. 
2. Ahmedabad Municipal Corporation (AMC) started a C\&D waste processing plant of capacity 1100 TPD in 2014 under a PPP agreement with Amdavad Enviro Projects Pvt. Ltd (AEP). The plant currently operates at 300 TPD and processes C\&D waste into aggregates, which in turn are used to prepare finished products such as paver blocks, concrete tiles, pre-cast toilets, park benches, etc. The preferential procurement policy of AMC facilitates the use of these products in government infrastructure projects.

3. A C\&D waste recycling plant was set up by M/s Enzyme India Pvt. Ltd in 2014 for recycling $150 \mathrm{TPD}$ of $\mathrm{C} \& \mathrm{D}$ waste at the project site of 'Re-development of East Kidwai Nagar, New Delhi'. The plant worked on PPP agreement with 100\% buyback of recycled products by National Buildings Construction Corporation (NBCC). The recycled produce such as fine/coarse aggregates and manufactured soil were used as fill material and in the manufacture of downstream products like RMC, bricks, tiles, and blocks.

4. A non-governmental organization named 'Youth for Unity and Voluntary Action (YUVA)' undertook

recycling of 1500 tonnes of $\mathrm{C} \& \mathrm{D}$ waste generated from City and Industrial Development Corporation of Maharashtra Ltd (CIDCO)- YUVA Building Center (CYBC) in Kharghar, Mumbai during the period 2002-2006. The C\&D recycling demonstration manufactured building materials such as bricks, blocks, concrete, sand substitute, and coarse aggregates.

\section{CONCLUTION}

Demolition waste is waste debris from destruction of a construction. Construction industry in India generates about 10-12 million Tons of waste annually. While Retrievable items like bricks, wood, metal, titles are recycled in India, Concrete and masonry waste $(>50 \%$ of total waste $)$ are not recycled. A defined manual is not available with regulatory authorities for effective management of Construction and Demolition (C \& D) waste. Authorities sometimes make rules but often fail in implementing them. This report is expected to be a pilot study towards preparation of such a manual. The two-faced problem of meeting the demand for construction materials as well as processing of large quantities of unprocessed waste has led to the development of important C\&D waste management measures in India. Waste management legislations in India have emerged as a natural consequence of the need to ensure effective C\&D waste management, culminating in the formulation of a separate C\&D Waste Management Rules 2016 by the government. However, due to lack of C\&D waste processing awareness among the regulators, operators, and the general public, the potential for usage of recycled products in the Indian construction sector is still untapped. The C\&D Rules of 2016 were followed by several guidelines and revisions in important material usage standards for concrete (IS 383: 2016, IRC 121: 2017). It is important to comprehend the best practices of C\&D waste management adopted by cities like Delhi and Ahmedabad and reproduce their business models at other operational and proposed C\&D waste recycling plants across India.

\section{REFRENCES}

1. Administrative Staff College of India (ASCI) and Natural Resources Defense Council (NRDC) (2012) Constructing Change: Accelerating Energy Efficiency in India's Buildings Market. New York: Natural Resources Defense Council.

2. Building Materials \& Technology Promotion Council (BMTPC) (2018) Utilisation of Recycled Produce of Construction \& Demolition Waste: A Ready Reckoner. New Delhi: Building Materials \& Technology Promo

3. tion Council, Ministry of Housing and Urban Affairs, Government of India.

4. Bureau of Indian Standards (BIS) (2016) National Building Code of India 2016. Vol. 2. New Delhi: Bureau of Indian Standards, Ministry of Consumer Affairs, Food and Public Distribution, Government of India.

5. Center for Study of Science, Technology and Policy (CSTEP) (2016) Construction and Demolition Waste Utilisation for Recycled Products in Bengaluru: Challenges and Prospects. New Delhi: Deutsche Gesellschaft

6. für Internationale Zusammenarbeit (GIZ) $\mathrm{GmbH}$.

7. Central Pollution Control Board (CPCB) (2017) Guidelines on Environmental Management of Construction \& Demolition $(C \& D)$ Wastes. New Delhi: Central Pollution Control Board, Ministry of Environment, Forest and Climate Change.

8. Central Pollution Control Board (CPCB), Ministry of Environment, Forest and Climate Change (MoEFCC), Ministry of Housing and Urban Affairs (MoHUA) and National Productivity Council (NPC) (2017) Toolkit on Construction and Demolition Waste Management Rules-2016: Capacity Building Programme on Implementation of Waste Management Rules, 2016 (Draft). Available at:http://www.npcindia.gov.in/wp-content/ uploads/2017/11/CD-Waste-ManagementToolKit-2017_R-1.pdf (accessed 16 September 2019).

9. Centre for Science and Environment (CSE) (2011) Buildings: Earthscrapers Environment Impact Assessment of Buildings. New Delhi: Centre for Science and Environment. 
10. Centre for Science and Environment (CSE) (2014) Construction and Demolition Waste. New Delhi: Centre for Science and Environment.

11. Department of Industrial Policy and Promotion (2011) Report of Working Group on Cement Industry for XII Five Year Plan (2012-17). New Delhi:

12. Department of Industrial Policy and Promotion, Ministry of Commerce and Industry, Government of India.

13. Development Alternatives (2017) Training Manual on Construction and Demolition Waste Management in India for Cities and Towns. New Delhi:

14. Government of NCT of Delhi (2018) Use of Recycled Products from Construction \& Demolition Waste (Advisory). New Delhi: Government of NCT of Delhi.

15. Indian Roads Congress (IRC) (2017) IRC 1212017: Guidelines for Use of Construction and Demolition Waste in Road Sector. New Delhi: Indian Roads Congress.

16. Indian Standard (IS) 383 (2016) Coarse and Fine Aggregate for Concrete - Specification (third revision).

17. Indo-German Environment Partnership (IGEP) (2013) India's Future Needs for Resources: Dimensions, Challenges, and Possible Solutions. New Delhi: Deutsche Gesellschaft f'r Internationale Zusammenarbeit (GIZ) GmbH.

18. International Energy Agency (IEA) and World Business Council on Sustainable Development (WBCSD) Cement Sustainability Initiative (CSI)
(2018) Technology Roadmap: Low-Carbon Transition in the Cement

19. Industry. Paris: International Energy Agency.

20. Ministry of Housing and Urban Affairs (MoHUA) and NITI Aayog (2018) Strategy for Promoting Processing of Construction and Demolition $(C \& D)$ Waste and Utilisation of Recycled Products. New Delhi: Ministry of Housing and Urban Affairs.

21. A mini review of construction and demolition waste management in India (M Humam Zaim Faruqi and Faisal Zia Siddiqui)

22. Ministry of Environment, Forest and Climate Change (MoEFCC) (2016) Construction and Demolition Waste Management Rules, 2016. Available at: https://cpcb.nic.in/uploads/MSW/SWM_2016.pdf (accessed 29 September 2019).

23. The Energy and Resources Institute (TERI), Development Alternatives (DA) and Deutsche Gesellschaft für Internationale Zusammenarbeit (GIZ) GmbH (2016) Material Consumption Patterns in India: A Baseline Study

24. of the Automotive and Construction Sectors. New Delhi: Deutsche Gesellschaft für Internationale Zusammenarbeit GmbH.

25. The World Bank Group (2019) Urban Population: World bank staff estimates based on the United Nations Population Division's World Urbanization Prospects (2018 Revision). Available at:https://data.worldbank.org/indi cator/SP.URB.TOTL? end $1 / 42018 \% 20 \&$ start $1 / 4196^{1}$ O\&\%20view1/4chart (accessed 25 September 2019). 